\title{
Prevalence, Trends and Conditions for the DTP3 Vaccine: A 25-Year Historical Perspective
}

\author{
Ana Amélia Corrêa de Araújo \\ Veras (iD) \\ Suely Arruda Vidal (D) \\ Vilma Costa de Macêdo (iD ${ }^{2}$ \\ Marília de Carvalho \\ Lima ${ }^{3}{ }^{3}$ \\ Pedro Israel Cabral de Lira (iD ${ }^{3}$ \\ Eduardo Jorge da Fonseca \\ Lima (ID) \\ Malaquias Batista Filho (D) \\ 'Programa de Pós-graduação em \\ Medicina Integral, Instituto de Medicina \\ Integral Professor Fernando Figueira, \\ Recife, Pernambuco, Brazil; \\ ${ }^{2}$ Departamento de Enfermagem, \\ Universidade Federal de Pernambuco, \\ Recife, Pernambuco, Brazil; ${ }^{3}$ Programa de \\ Pós-graduação em Saúde da Criança e \\ Adolescente, Universidade Federal de \\ Pernambuco, Recife, PE, Brazil
}

Correspondence: Ana Amélia Corrêa de Araújo Veras

Programa de Pós-Graduação em Saúde Materno Infantil, Instituto de Medicina Integral Professor Fernando Figueira, Rua dos Coelhos, 300, Boa Vista, Recife, Pernambuco, CEP: 50.070-550, Brazil Email anamelia.av@gmail.com
Background: The aim was to verify the prevalence of vaccination coverage, tendency and factors of the third dose of the vaccine against diphtheria, tetanus and pertussis-DTP3 in surveys over the period of 25 years in a state of the Northeast of Brazil.

Methods: Cross-sectional and temporal series, utilizing ad hoc database, were extracted from the Health and Nutrition State Research 1991, 1997, 2006 and 2015/2016. Children from 12 to 23 months of age with proof in the vaccination card were included. The vaccination coverage (outcome) of each year was calculated, the tendency throughout the period was analyzed and the associations through Pearson chi-squared were tested. The results of the first and last survey were compared with a significance level of $5 \%$. The reasons of the crude prevalence and confidence intervals of $95 \%$ were estimated.

Results: The vaccination coverage in 1991, 1997, 2006 and $2015 / 2016$ was $77.6 \%, 82.7 \%$, $89.7 \%$ and $72.9 \%$, respectively, with an increasing tendency from 1991 to $2006(\mathrm{p}<0.001)$ and decreasing between 2006 and 2015/2016 ( $<<0.001$ ). Factors in 1991: low socioeconomic conditions; lack of access to health service and pre-natal care, nutritional deficit and diarrhea in children $(\mathrm{p}<0.005)$. In $2015 / 2016$, low socioeconomic conditions and diarrhea persisted and a larger family size, black, negative self-perception of happiness, both from the mother $(\mathrm{p}<0.05)$, were identified.

Conclusion: The factors of the recent decrease of vaccination coverage are complex, multifactorial, dependent of context and even on subjective aspects of the maternal perception. Its identification contributed to the understanding of inadequate vaccination at the state level.

Keywords: vaccination coverage/DTP3, child health, epidemiologic surveys, family characteristics

\section{Introduction}

Immunization is the most cost-effective public health intervention capable of preventing 2 to 3 million child deaths per year worldwide. ${ }^{1}$ Smallpox was eliminated by vaccination, and the world is closer to eradicate childhood poliomyelitis. ${ }^{2}$ Despite these results and the advances in vaccination coverage, it is estimated that millions of children have not been fully immunized with the third dose of diphtheria, tetanus, and pertussis vaccines (DTP3). ${ }^{3}$

DTP3 is considered a proxy for the complete sequence of basic vaccines recommended in childhood ${ }^{4}$ and a signal of how well countries promote routine immunization services. ${ }^{1}$ It is a marker of health service quality since it assesses the ability to reach the same child and perform the three injectable doses. ${ }^{5}$ It is also frequently used as a critical indicator to assess the adequate performance of health 
institutions related to the immunization program, favoring monitoring vaccination coverage and comparison between countries. $^{6}$

The Pan American Health Organization (PAHO) Strategic Plan 2014-2019 for the member states established an increase in vaccination coverage for the hardto-reach population of the Region of the Americas, with an average percentage of $94 \%$ for the DTP $3 .^{7}$ This indicator was signed in 2015 between the United Nations and 193 countries, including Brazil, and included in the 2030 agenda for sustainable development. Of note, the third Sustainable Development Goal describes health goals and emphasizes equity - leaving no one behind. ${ }^{8,9}$

DTP3 coverage dropped to $88 \%$ in the Region of the Americas in 2017, leaving approximately 1.8 million children under one year of age at risk. ${ }^{10}$ In 2019, approximately $85 \%$ of the child population worldwide received DTP3, a stable number over the past five years but below the recommended. In that same year, 125 countries reached at least 90\% coverage; however, 19.7 million children under one year of age did not receive the vaccine, and approximately $60 \%$ of them lived in 10 countries, including Brazil. ${ }^{10}$ Also, in the Region of the Americas, DTP3 coverage dropped to $88 \%$ in 2017 , leaving -approximately 1.8 million children under one year of age at risk. ${ }^{11}$

From 1991 to 2006, the DTP3 coverage increased to $103.5 \%$ in Brazil. This result can be attributed to greater access to primary care, socioeconomic improvements, and direct cash transfer programs in which immunization is one of the conditionalities; ${ }^{12}$ however, a notable decline in vaccination coverage has been observed in Brazil (from $96.3 \%$ in 2015 to $89.3 \%$ in 2016 and $83.8 \%$ in 2017). In the state of Pernambuco, DTP3 coverage was $103.5 \%$ in 2015 , decreased to $94.3 \%$ in 2016 , and reached $85.8 \%$ in 2017. This decrease can be related to multiple factors and requires a contextualized assessment. Some aspects (ie, prenatal care, maternal education, parents' knowledge about immunization, proximity to the health service, and birth in a hospital) positively affect the DTP3 indicator. Simultaneously, other aspects may interfere negatively with vaccination coverage, such as many family members, a high number of children, low frequency of prenatal consultations, low income, and lack of safe household sanitation. $^{13}$

In this context, and considering both the lack of studies regarding DTP3 coverage in Brazil and the availability of four State Health and Nutrition Survey (PESN) databases adopting the same methodological design, this study aimed to investigate vaccination coverage prevalence and trends and conditions related to the third DTP3 dose over 25 years in a Northeast state of Brazil.

\section{Materials and Methods}

Four surveys (PESN) were conducted in the state of Pernambuco in the following years: 1991, 1997, 2006, and 2015/2016 (unpublished report). A cross-sectional design was used with a cluster sampling process, multiple-stage drawing, selection of municipalities, and census sectors, in which all households with children under five years old were visited. The study was approved by the research ethics committee of the Instituto de Medicina Integral Professor Fernando Figueira (CAAE $\mathrm{N}^{\circ}$ 61944716.6.0000.5201) and conducted according to the Declaration of Helsinki.

The present study used these surveys' database, and all children aged between 12 and 23 months with confirmed DTP3 doses in the vaccination card were included. There were 152 children in 1991, 370 in 1997, 348 in 2006, and 177 in 2015/2016, totaling 1047 children.

Pernambuco state is located in the Brazilian Northeast region and has 9,410,336 inhabitants (estimated for 2019) distributed in 185 municipalities. The primary health care is conducted through the Family Health Strategy (FHS), covers $77 \%$ of the population, and has 2428 teams and 15,807 community health workers ( $\mathrm{CHW}$ ) registered in the primary care system.

DTP3 coverage was the primary outcome, classified as adequate (at least three doses were registered) and inadequate (did not meet this criterion). The DTP vaccine was initially administered as a triple bacterial isolate. Tetra bacterial (DTP + Haemophilus influenza-Hib) was introduced in 2003, but it was replaced by the pentavalent vaccine (DTP + Hib + Hepatitis B) in 2012.

Independent variables were divided into socioeconomic and demographic variables (family income and per capita income, residential area, household occupation, family size, and access to health services, piped water and sanitation), maternal (age, skin color, literacy, education, number of children born alive, prenatal care, number of prenatal consultations, type of delivery, and the mother's perception of happiness), and characteristics related to the child (sex, birth weight, place of birth, diarrhea, nutritional status [height/age indicator], and consultation with health care service). The access to health services considered the regular $\mathrm{CHW}$ visits and the distance from the unit most used by the family. 
The income variable in 1991, 1997 and 2006 was categorized according to the minimum wage received by the family, while the criterion adopted by the Brazilian Association of Research Companies was used for economy classification in 2015/2016. Classes D and E (ie, income less than one minimum wage) were selected and compared between the first and last surveys.

Sample size calculation considered the prevalence of malnutrition in children under five years old. Categorical variables are presented as absolute and relative frequencies and quantitative variables as mean and standard deviation.

Some variables (ie, residential area, access to water, literacy, maternal age, prenatal care, sex of the child, and diarrhea) were compared between children with and without vaccination card (22.8\% in 1991 and $10.6 \%$ in 1997) to assess selection bias. Associations between socioeconomic and demographic variables and maternal and child characteristics were performed using the Chi-square test. Associations between independent variables and DTP3 coverage were analyzed using Poisson regression with robust variance, and results were presented as gross prevalence ratio and $95 \%$ confidence intervals $(95 \% \mathrm{CI})$. The lowest risk for inadequate vaccination coverage was considered the category of reference.
Ad hoc databases were built for each survey with variables based on a theoretical framework and its availability. Factors related to inadequate vaccination were verified in all four surveys; however, comparisons were performed using 18 variables of the first survey (1991) and 19 variables of the last survey (2015/2016). DTP3 coverage in each survey was calculated as the quotient between the number of children aging 12-23 months that received the adequate doses and the total number of children in that age group multiplied by 100 .

Inferential analyses were performed using the STATA program version 14 (College Station, TX: Stata Corp LP), and a significance level of $<0.05$ (2-tailed) was adopted for all statistical analyses.

\section{Results}

The percentage of DTP3 coverage in the 1991, 1997, 2006, and 2015/2016 surveys was $77.6 \%$ (95\% CI: $70.2-$ $84 \%), \quad 82.7 \% \quad(95 \%$ CI: $78-86 \%), \quad 89.7 \% \quad(95 \%$ CI: 86-93\%), and 72.9\% (95\% CI: 72.5-73.3\%), respectively. These results are represented in Figure 1 and compared with data for the state of Pernambuco and Brazil.

Trends over 25 years in childhood morbidity and socioeconomic, demographic, and maternal variables are shown in Table 1. Family income distribution in the period

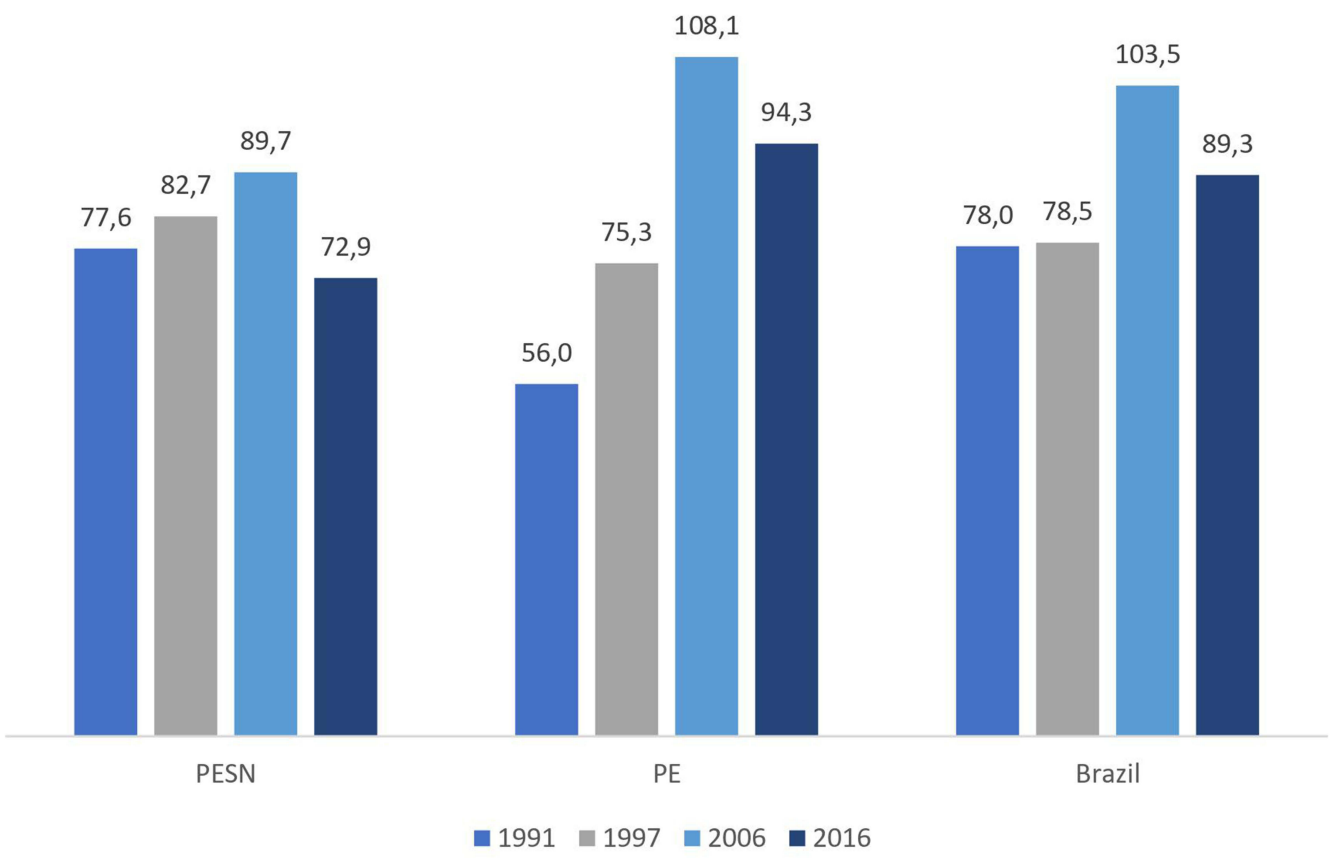

Figure I Vaccination coverage for DTP3* in children aged 12 to 23 months obtained in the State Health and Nutrition Surveys (PESN) (Pernambuco state and Brazil) in 1991, 1997, 2006, and 2016.

Notes: *DTP3: third dose of the diphtheria, tetanus, and pertussis vaccines. State Health and Nutrition Survey (PESN): increasing trend from I99I to 2006 ( $=0.00 \mathrm{I})$ and decreasing trend from 2006 to 20I5/16 ( $<<0.001$ ). Sources: API/CGPNI/DEVEP/SVS/MS (1980 to 1993). Data from the former information system of the Ministry of Health provided by the National Immunization Program. From 1994: http://tabnet.datasus.gov.br/cgi/tabcgi.exe?pni/cnv/cpniuf.def. Percentages of Pernambuco state and Brazil correspond to 2016 and the age group up to 12 months. 
Table I Prevalence Ratio of Inadequate DTP3 Vaccination Coverage in Children Aged Between 12 and 23 Months, According to Socioeconomic and Demographic Variables, Maternal Characteristics, Children's Characteristics and Morbidity. State Health and Nutrition Survey in Pernambuco (PESN), 1991 to 2015/2016

\begin{tabular}{|c|c|c|c|c|c|c|}
\hline \multirow[t]{4}{*}{ Variables } & \multicolumn{4}{|c|}{ Surveys } & \multirow{4}{*}{$\begin{array}{c}p^{* *} \\
(1991-2015 / \\
16)\end{array}$} & \multirow{4}{*}{$\begin{array}{c}\mathbf{P}^{* *} \\
\text { (All Years) }\end{array}$} \\
\hline & \multirow{2}{*}{$\begin{array}{l}1991 \\
n=152\end{array}$} & \multirow{2}{*}{$\begin{array}{c}1997 \\
n=370\end{array}$} & \multirow{2}{*}{$\begin{array}{c}2006 \\
n=348\end{array}$} & \multirow{2}{*}{$\begin{array}{c}2015 / 2016 \\
n=177\end{array}$} & & \\
\hline & & & & & & \\
\hline & n (\%) & n (\%) & n (\%) & n (\%) & & \\
\hline Male & $85(56.0)$ & $166(44.9)$ & $176(50.6)$ & $97(54.8)$ & 0.839 & 0.052 \\
\hline Family income $\leq$ I wage & $76(50.0)$ & $176(47.5)$ & $156(44.9)$ & $85(48.0)$ & 0.721 & 0.723 \\
\hline Family ( $\leq 4$ people) & $62(40.8)$ & 147 (39.7) & $176(50.6)$ & $105(59.3)$ & $<0.001$ & $<0.001$ \\
\hline Piped water & $67(44.1)$ & $227(6 \mid .3)$ & $168(48.3)$ & I44 (8I.4) & $<0.001$ & $<0.001$ \\
\hline Sewerage & $86(56.6)$ & $225(60.8)$ & $224(64.4)$ & $138(78.0)$ & $<0.001$ & $<0.001$ \\
\hline Health Service Access (<2km) & $95(62.5)$ & $259(70.0)$ & A & $148(83.6)$ & $<0.001$ & $<0.001$ \\
\hline Regular $\mathrm{CHW}$ visit & B & $127(34.3)$ & 291 (83.6) & $|3|(74.0)$ & $(\ldots)$ & $<0.001$ \\
\hline Mother's age $\leq 19$ years & $16(10.7)$ & $39(10.5)$ & $29(8.4)$ & $32(18.3)$ & 0.060 & 0.009 \\
\hline Maternal education & $94(61.8)$ & $262(70.8)$ & $280(80.5)$ & $\mathrm{C}$ & $(\ldots)$ & $<0.001$ \\
\hline Maternal schooling (Incomplete elementary) & $73(49.0)$ & $281(76.0)$ & $229(65.8)$ & $116(65.7)$ & 0.003 & $<0.001$ \\
\hline Prenatal care & $106(69.7)$ & $309(83.5)$ & $337(96.8)$ & I 75 (98.9) & $<0.001$ & $<0.001$ \\
\hline Prenatal consultations $(\geq 6)$ & $48(46.2)$ & $173(56.0)$ & $226(67.1)$ & I27 (7I.8) & $<0.001$ & $<0.001$ \\
\hline Birth in hospital & I39 (9l.4) & $337(91.0)$ & $332(95.4)$ & $177(100.0)$ & $\mathrm{D}$ & 0.06 \\
\hline Cesarean delivery & $29(21.7)$ & $104(28.1)$ & I0I (29.0) & I0I (57.I) & $<0.001$ & $<0.001$ \\
\hline Nutritional deficit $(<-2 S \mathrm{~S}$ for $\mathrm{H} / \mathrm{A})$ & $41(27.0)$ & $66(18.0)$ & $122(35.2)$ & $15(8.5)$ & $<0.001$ & $<0.001$ \\
\hline Diarrhea (last 2 weeks) & $43(28.3)$ & $108(29.2)$ & $36(10.3)$ & $4 \mid(23.2)$ & 0.288 & $<0.001$ \\
\hline Consultation (last 3 months) & $64(42.1)$ & $196(53.0)$ & $230(66.1)$ & $118(66.7)$ & $<0.001$ & $<0.001$ \\
\hline
\end{tabular}

Notes: (**) Chi-squared. (...) Not calculated. (A) The high percentage of people who ignored (53.2\%) made the comparison impossible; (B) Information not collected in this survey, began in 1997; (C) Variable aggregated in another category; (D) All births in 2015 took place in a hospital. Source: prepared by the authors from the study results. Abbreviations: DTP3, third dose of the diphtheria, tetanus, and pertussis vaccines; km, kilometer; SD, standard deviation; H/A, height/age indicator.

mentioned above remained practically unchanged, while the access to piped water and sanitary sewage increased significantly $(\mathrm{p}<0.001)$. An increase in these two indicators, especially the CHW monitoring, was observed. Regarding maternal characteristics, the increased number of adolescent mothers and cesarean deliveries (57.1\%, more than a two-fold increase compared with 1991) in the last survey was noteworthy. Conversely, diarrhea and nutritional deficit (height/age indicator) were reduced.

Bivariate analysis related to inadequate vaccination coverage in the first survey (1991) are shown in Table 2. Low per capita income, maternal education, absence of sanitation and prenatal care, more than five children, and difficulties in accessing the health care service were factors associated with inadequate vaccination coverage. Inadequate nutritional status and non-attendance in health care services were the children's characteristics associated with low vaccination coverage.

Data related to the 2015/2016 survey are shown in Table 3. More than five family members, households without sanitation, diarrhea in the last two weeks, the negative self-perception of happiness, and the black skin color of the mother were significantly associated with low vaccination coverage.

\section{Discussion}

The present study investigated the vaccination coverage prevalence and trends and verified the factors associated with DTP3 inadequacy in children aged 12 to 23 months in the state of Pernambuco.

A growing trend in vaccination coverage was observed between 1991 and 2006. However, the percentage of children who received DTP3 in 2015 was below the normative recommendations. Values found in the surveys were compared with those obtained by the Unified Health System (SUS) for Brazil and Pernambuco, and the same trend was observed by the National Immunization Program (NIP). The health care model that prioritizes acute health conditions independent of primary care surveillance, prevention, and promotion was probably critical for this reduction. ${ }^{14}$

Some reasons are responsible for the decline in vaccination rates in different countries, such as political and 
Table 2 Prevalence Ratio of Inadequate DTP3 Vaccination Coverage in Children Aged Between 12 and 23 Months, According to Socioeconomic and Demographic Variables, Maternal Characteristics, Children's Characteristics and Morbidity. State Health and Nutrition Survey in Pernambuco (PESN), 1991

\begin{tabular}{|c|c|c|c|c|}
\hline \multirow[t]{2}{*}{ Variables } & \multirow{2}{*}{$\begin{array}{l}\text { Total } \\
\text { n (\%) }\end{array}$} & \multicolumn{3}{|c|}{ Inadequate Vaccine Coverage } \\
\hline & & n (\%) & $\begin{array}{c}\text { Gross Prevalence Ratio } \\
\text { (IC 95\%) }\end{array}$ & $p$ \\
\hline \multicolumn{5}{|c|}{ Socioeconomic and Demographic } \\
\hline $\begin{array}{l}\text { Family income } \\
<\text { I minimum wage } \\
\geq \text { I minimum wage }\end{array}$ & $\begin{array}{l}76(50) \\
76(50)\end{array}$ & $\begin{array}{l}13(17.1) \\
21(27.6)\end{array}$ & $\begin{array}{c}1.00 \\
1.62(0.87-2.99)\end{array}$ & 0.122 \\
\hline $\begin{array}{l}\text { Per capita income } \\
\geq 0.25 \text { minimum wage } \\
<0.25 \text { minimum wage }\end{array}$ & $\begin{array}{l}64(42.1) \\
88(57.9)\end{array}$ & $\begin{array}{c}7(10.9) \\
27(30.7)\end{array}$ & $\begin{array}{c}1.00 \\
2.80(1.30-6.04)\end{array}$ & 0.008 \\
\hline $\begin{array}{l}\text { Family size } \\
\text { Up to } 4 \text { people } \\
\geq 5 \text { people }\end{array}$ & $\begin{array}{l}62(40.8) \\
90(59.2)\end{array}$ & $\begin{array}{l}66(16.1) \\
24(26.7)\end{array}$ & $\begin{array}{c}1.00 \\
1.65(0.85-3.21)\end{array}$ & 0.137 \\
\hline $\begin{array}{l}\text { Sewerage } \\
\text { Yes } \\
\text { No }\end{array}$ & $\begin{array}{l}86(56.6) \\
66(43.4)\end{array}$ & $\begin{array}{l}\text { II (12.8) } \\
23(34.8)\end{array}$ & $\begin{array}{c}1.00 \\
2.72(1.43-5.18)\end{array}$ & 0.002 \\
\hline $\begin{array}{l}\text { Piped water } \\
\text { Yes } \\
\text { No }\end{array}$ & $\begin{array}{l}67(44.1) \\
85(55.9)\end{array}$ & $\begin{array}{c}8(11.9) \\
26(30.6)\end{array}$ & $\begin{array}{c}1.00 \\
2.56(1.24-5.29)\end{array}$ & 0.011 \\
\hline $\begin{array}{l}\text { Access to health service } \\
<2 \text { kilometers } \\
\geq 2 \text { kilometers }\end{array}$ & $\begin{array}{l}109(71.7) \\
43(28.3)\end{array}$ & $\begin{array}{l}20(18.3) \\
14(32.6)\end{array}$ & $\begin{array}{c}1.00 \\
1.77(0.99-3.19)\end{array}$ & 0.055 \\
\hline \multicolumn{5}{|c|}{ Maternal characteristics } \\
\hline $\begin{array}{l}\text { Age } \\
\leq 19 \text { years } \\
20 \text { to } 34 \text { years } \\
\geq 35 \text { years }\end{array}$ & $\begin{array}{l}16(10.7) \\
114(76.0) \\
20(13.3)\end{array}$ & $\begin{array}{c}2(12.5) \\
22(19.3) \\
8(40.0)\end{array}$ & $\begin{array}{c}1.00 \\
1.54(0.40-5.95) \\
3.20(0.70-13.02)\end{array}$ & $\begin{array}{l}0.075 \\
0.399 \\
0.071\end{array}$ \\
\hline $\begin{array}{l}\text { Education } \\
\geq \text { Incomplete elementary } \\
\leq \text { Complete elementary }\end{array}$ & $\begin{array}{l}77(50.7) \\
75(49.3)\end{array}$ & $\begin{array}{c}8(10.4) \\
25(34.7)\end{array}$ & $\begin{array}{c}1.00 \\
3.37(1.57-6.76)\end{array}$ & 0.001 \\
\hline $\begin{array}{l}\text { Children born alive } \\
\leq 4 \text { children } \\
\geq 5 \text { children }\end{array}$ & $\begin{array}{l}119(79.9) \\
33(20.1)\end{array}$ & $\begin{array}{l}19(16.0) \\
13(45.5)\end{array}$ & $\begin{array}{c}1.00 \\
4.02(1.63-4.97)\end{array}$ & $<0.001$ \\
\hline $\begin{array}{l}\text { Prenatal care } \\
\text { Yes } \\
\text { No }\end{array}$ & $\begin{array}{l}106(69.7) \\
46(30.3)\end{array}$ & $\begin{array}{l}12(11.3) \\
22(47.8)\end{array}$ & $\begin{array}{c}1.00 \\
1.24(1.15-1.36)\end{array}$ & $<0.001$ \\
\hline $\begin{array}{l}\text { Prenatal consultations } \\
\geq 6 \\
\text { I a } 5\end{array}$ & $\begin{array}{l}48(46.2) \\
56(53.8)\end{array}$ & $\begin{array}{c}\text { I }(2.1) \\
\text { II }(19.6)\end{array}$ & $\begin{array}{c}1.00 \\
9.43(1.26-70.4 I)\end{array}$ & 0.005 \\
\hline $\begin{array}{l}\text { Type of delivery } \\
\text { Cesarean } \\
\text { Vaginal }\end{array}$ & $\begin{array}{l}29(21.7) \\
123(78.3)\end{array}$ & $\begin{array}{c}3(10.3) \\
31(25.2)\end{array}$ & $\begin{array}{c}1.00 \\
2.92(0.82-10.32)\end{array}$ & 0.096 \\
\hline
\end{tabular}


Table 2 (Continued).

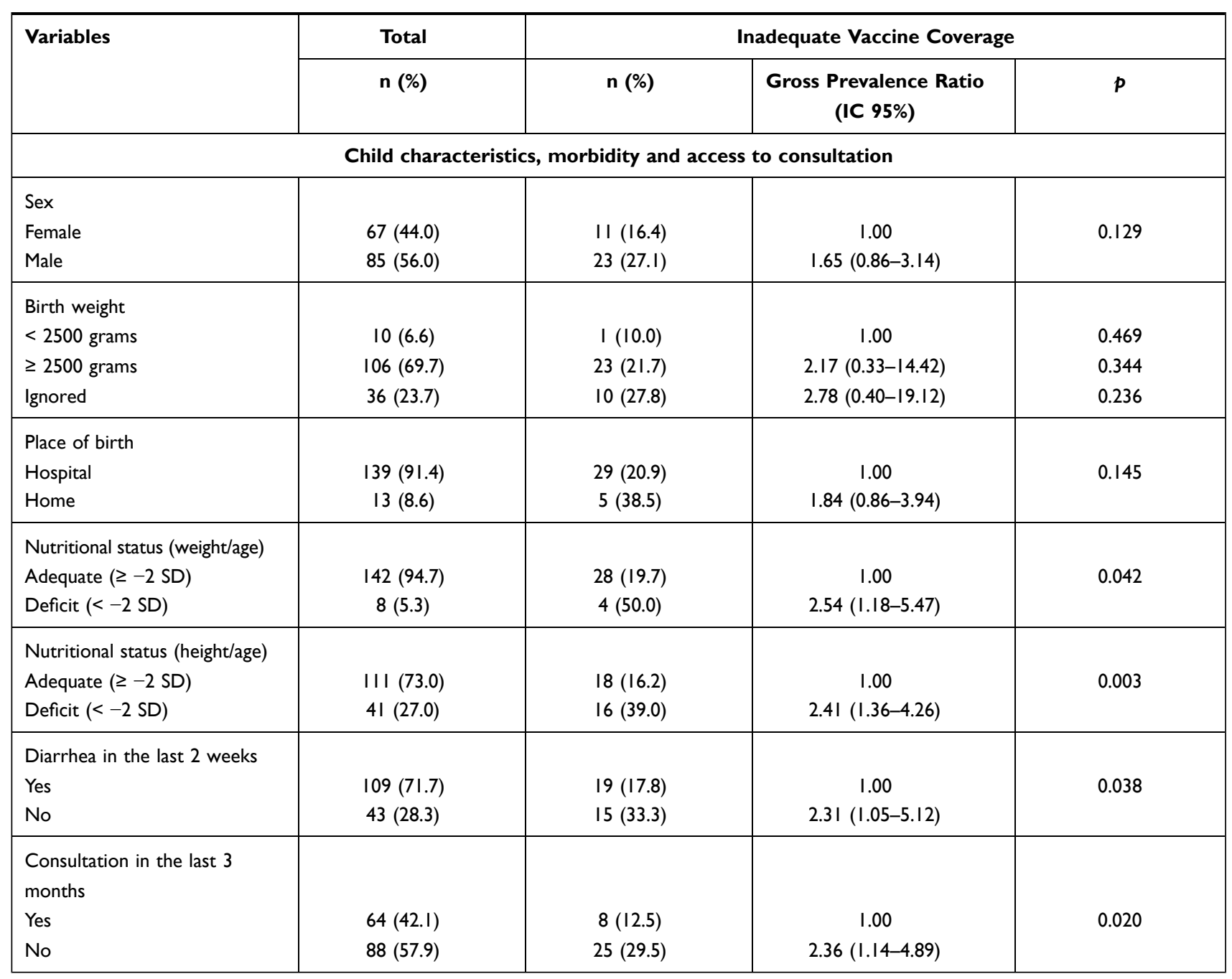

Note: Source: prepared by the authors from the study results.

Abbreviations: DTP3, third dose of the diphtheria, tetanus, and pertussis vaccines; SD, standard deviation.

economic fragilities, lack of health service monitoring, the false sense of security concerning illness, the growing anti-vaccine movement, dissemination of false information, and the funding crisis. ${ }^{15,16}$ In Brazil, the Constitutional Amendment 95 approved in December 2016 impacted public health financing (budget restrictions) and aggravated the immunization decline. ${ }^{17}$

The reduced vaccination coverage from 2015 indicates a trend reversal and should put health researchers and policymakers on alert since it is not a singular event in the health care situation of the state of Pernambuco. Stagnation has complex causes and can be partially attributed to insecurity (ie, vaccination refusal or reluctance), despite the vaccine availability. Studies also identified compliance and lack of confidence as primary reasons behind the growing resistance against vaccination in most countries. ${ }^{18,19}$ The World Health Organization (WHO) warned about this phenomenon and considered it one of the ten global health threats to face in the next five years (2019 to 2023). ${ }^{20}$

Changes in the Brazilian population may have also impacted maternal and child health during the survey applications in Pernambuco, such as the rapid demographic (fertility fall), economic (poverty reduction), nutritional (overcoming malnutrition and overweight/obesity), and epidemiological transitions (urbanization). ${ }^{21}$ The organization of health services, together with interventions outside the health sector (ie, the conditional cash transfer program, treated water supply, and residential sanitation) and the SUS implementation, resulted in great health outcome improvements. ${ }^{22-24}$ 
Table 3 Prevalence Ratio of Inadequate DTP3 Vaccination Coverage in Children Aged Between 12 and 23 Months, According to Socioeconomic and Demographic Variables, Maternal Characteristics, Children's Characteristics and Morbidity. State Health and Nutrition Survey in Pernambuco (PESN), 2015/2016

\begin{tabular}{|c|c|c|c|c|}
\hline \multirow[t]{2}{*}{ Variables } & \multirow{2}{*}{$\begin{array}{l}\text { Total } \\
\text { n (\%) }\end{array}$} & \multicolumn{3}{|c|}{ Inadequate Vaccine Coverage } \\
\hline & & n (\%) & $\begin{array}{c}\text { Gross Prevalence Ratio } \\
\text { (IC 95\%) }\end{array}$ & $\mathbf{p}$ \\
\hline \multicolumn{5}{|c|}{ Socioeconomic and demographic } \\
\hline \multicolumn{5}{|l|}{ Economic class of the family } \\
\hline $\mathrm{B}$ and $\mathrm{Cl}$ & $34(19.2)$ & $6(17.6)$ & 1.00 & 0.284 \\
\hline $\mathrm{C} 2$ & $58(32.8)$ & $15(25.9)$ & $1.07(0.93-1.23)$ & 0.348 \\
\hline$D$ and $E$ & $85(48.0)$ & $27(3 \mid .8)$ & $1.12(0.98-1.28)$ & 0.093 \\
\hline \multicolumn{5}{|l|}{ Family size } \\
\hline Up to 4 people & $105(59.3)$ & $22(21.0)$ & 1.00 & 0.026 \\
\hline$\geq 5$ people & $72(40.7)$ & $26(36.1)$ & $1.13(1.01-1.25)$ & \\
\hline \multicolumn{5}{|l|}{ Sewerage } \\
\hline Yes & $138(78.0)$ & $27(19.6)$ & 1.00 & $<0.001$ \\
\hline No & $39(22.0)$ & $21(53.8)$ & $1.29(1.15-1.45)$ & \\
\hline \multicolumn{5}{|l|}{ Piped water } \\
\hline Yes & |44 (8I.4) & $35(24.3)$ & 1.00 & 0.123 \\
\hline No & $33(18.6)$ & $13(39.4)$ & $1.62(0.97-2.70)$ & \\
\hline \multicolumn{5}{|l|}{ Access to health service } \\
\hline On foot & I48 (83.6) & $37(25.0)$ & 1.00 & 0.167 \\
\hline Car/Other & $29(16.4)$ & II (37.9) & $1.10(0.96-1.27)$ & \\
\hline \multicolumn{5}{|c|}{ Maternal characteristics } \\
\hline \multicolumn{5}{|l|}{ Age } \\
\hline$\leq 19$ years & $31(18.3)$ & $7(22.6)$ & 1.00 & 0.605 \\
\hline 20 to 34 years & $80((47.3)$ & $25(3 \mid .2)$ & $1.07(0.93-1.24)$ & 0.348 \\
\hline$\geq 35$ years & $58(34.3)$ & $15(25.9)$ & $1.03(0.88-1.19)$ & 0.730 \\
\hline \multicolumn{5}{|l|}{ Education } \\
\hline$\geq$ Complete elementary & III (65.7) & $26(23.4)$ & 1.00 & 0.082 \\
\hline$\leq$ Incomplete elementary & $58(34.3)$ & $21(36.2)$ & $1.10(0.99-1.23)$ & \\
\hline \multicolumn{5}{|l|}{ Children born alive } \\
\hline One & $63(37.9)$ & $12(19.0)$ & 1.00 & 0.031 \\
\hline Two & $55(33.2)$ & $15(27.3)$ & $\mathrm{I} .07(0.95-1.2 \mathrm{I})$ & 0.288 \\
\hline$\geq$ Three & $48(28.9)$ & $20(4 \mid .7)$ & $1.19(1.05-1.35)$ & 0.008 \\
\hline \multicolumn{5}{|l|}{ Prenatal consultations } \\
\hline$\geq 6$ & $48(28.2)$ & $16(32.0)$ & 1.00 & 0.291 \\
\hline I a 5 & I27 (7I.8) & $32(25.2)$ & $0.94(0.84-1.06)$ & \\
\hline \multicolumn{5}{|l|}{ Type of delivery } \\
\hline Cesarean & $101(57.1)$ & $25(24.8)$ & 1.00 & 0.416 \\
\hline Vaginal & $76(42.9)$ & $23(30.3)$ & $1.22(0.76-1.98)$ & \\
\hline \multicolumn{5}{|l|}{ Mother's skin color } \\
\hline White & $36(21.3)$ & $8(22.2)$ & 1.00 & 0.009 \\
\hline Black & $17(10.1)$ & $10(58.8)$ & $1.30(1.08-1.56)$ & 0.005 \\
\hline Brown/Other & $116(68.6)$ & $29(25.0)$ & $1.02(0.90-1.16)$ & 0.730 \\
\hline \multicolumn{5}{|c|}{ Mother's self-perception of happiness } \\
\hline Positive & I5I (9I.0) & $39(25.8)$ & 1.00 & 0.026 \\
\hline Negative & $15(9.0)$ & $8(53.3)$ & $1.22(1.02-1.45)$ & \\
\hline
\end{tabular}


Table 3 (Continued).

\begin{tabular}{|c|c|c|c|c|}
\hline \multirow[t]{2}{*}{ Variables } & \multirow{2}{*}{$\begin{array}{l}\text { Total } \\
\text { n (\%) }\end{array}$} & \multicolumn{3}{|c|}{ Inadequate Vaccine Coverage } \\
\hline & & n (\%) & $\begin{array}{c}\text { Gross Prevalence Ratio } \\
\text { (IC 95\%) }\end{array}$ & $\mathbf{p}$ \\
\hline \multicolumn{5}{|c|}{ Child characteristics, morbidity and access to consultation } \\
\hline \multicolumn{5}{|l|}{ Sex } \\
\hline Female & $80(45.2)$ & $20(25.0)$ & 1.00 & 0.684 \\
\hline Male & $97(54.8)$ & $28(28.9)$ & I.I5 (07I-I.89) & \\
\hline \multicolumn{5}{|l|}{ Birth weight } \\
\hline$<2500$ grams & $160(90.4)$ & $42(26.2)$ & 1.00 & 0.404 \\
\hline$\geq 2500$ grams & $17(9.6)$ & $6(35.3)$ & $1.34(0.67-2.69)$ & \\
\hline \multicolumn{5}{|l|}{ Place of birth } \\
\hline Private hospital & $26(14.7)$ & $3(11.5)$ & 1.00 & 0.089 \\
\hline Public hospital & I5I (85.3) & $45(29.8)$ & $2.58(0.87-7.70)$ & \\
\hline \multicolumn{5}{|l|}{ Nutritional status (height/age) } \\
\hline Adequate $(\geq-2 \mathrm{SD})$ & $153(9 \mid .1)$ & $4 \mid(26.8)$ & 1.00 & 0.599 \\
\hline Deficit $(<-2$ SD) & $15(8.9)$ & $5(33.3)$ & $1.05(0.87 ;$ ।.27) & \\
\hline \multicolumn{5}{|l|}{ Diarrhea in the last 2 weeks } \\
\hline Yes & $136(76.8)$ & $31(22.8)$ & 1.00 & 0.022 \\
\hline No & $4 \mid(23.2)$ & $17(4 \mid .5)$ & $1.15(1.02-1.30)$ & \\
\hline \multicolumn{5}{|l|}{ Consultation in the last 3 months } \\
\hline Yes & 118 (66.7) & $27(22.9)$ & 1.00 & 0.07 \\
\hline No & $59(33.3)$ & $21(35.6)$ & $1.10(0.99-1.23)$ & \\
\hline
\end{tabular}

Note: Source: prepared by the authors from the study results.

Abbreviations: DTP3, third dose of the diphtheria, tetanus, and pertussis vaccines; SD, standard deviation.

Some trends are reflected in the sample (reduced family size, greater proximity to the health service, and regular CHA visits) and household characteristics (increased access to piped water and sanitation) over the 25 years. Maternal education and the number of adolescent mothers and cesarean deliveries also increased in 2015/2016.

Child health indicators have also changed, especially malnutrition, which was present in almost one-third of the children at the beginning of the historical series and reduced to $<10 \%$ at the end of the analyzed period. This gain may be partially attributed to the National Primary Care Policy that adopted the FHS model in 2006 to reorganize primary health care in the SUS, favoring greater access to medical care and health prevention and promotion. $^{25}$

It was also possible to observe that children with low birth weight and born in public hospitals were not associated with inadequate vaccination coverage. These children are identified early and monitored after birth by health professionals and CHAs, and guidance provided to their mothers may impact vaccination throughout the first year of life.
Factors associated with vaccination coverage must be investigated under several aspects due to multiple causes that range from structural issues related to health systems and services to ignorance regarding vaccine benefits, nonperception of risks, parental beliefs and fears about adverse events, insecurity about vaccine effectiveness, and influence of anti-vaccine movements. ${ }^{7,10,14,15,19,26}$

Bivariate analysis indicated that immunization inequality decreased over the study period since ten associated factors were present in 1991, while only six were identified in 2015. Three factors coincided in these two surveys: the number of children, access to sanitation, and diarrhea; and, despite advances, ${ }^{20,21}$ these limitations have not been fully overcome.

Vaccination inadequacy in the first survey (1991) was higher in children whose mothers did not perform prenatal care, corroborating the results of another study. ${ }^{21}$ The nonattendance in health services represented a 2.3 -fold higher probability of inadequate vaccination, indicating the importance of the contact with health professionals (considered reliable immunization advisers and influencers) ${ }^{25}$ and the 
opportunity to update the vaccination calendar (this variable was not statistically significant in 2015/2016).

Also, those children with nutritional deficits in the first survey were 2.4 -fold more likely to be inadequately vaccinated; however, this result was not observed in 2015/16, suggesting overcoming this condition. Possible explanations include cash transfer policies for children at nutritional risk (implemented in 2001 and subsequently expanded to all families with income below the poverty line $)^{27}$ and the expansion of health service access after CHA (1991) and FHP (1994) implementation. ${ }^{24}$ Children from low per capita income families and without access to piped water/sanitary sewage presented almost three-fold higher inadequate vaccination in 1991 than those with better socioeconomic, sanitary, and housing conditions. 5,6,21

Maternal education is an essential predictor of adequate health care and immunization status. ${ }^{25,28}$ In the present study, mothers with less schooling and more children were 3.4- and 4-fold, respectively, more likely to present incomplete DTP3 doses. The contribution of education to attitude, tradition, and belief changes, together with increasing autonomy and decision-making power, can stimulate better family health conditions, including child vaccination.

Families with more than five members showed a slightly higher prevalence of inadequate vaccination in $2015 / 2016$, which is consistent with studies conducted with children of the same age group. ${ }^{13,29}$ Larger families may affect the mother's ability to care for the child and the time to take $\mathrm{him} /$ her to vaccinate. ${ }^{18}$

Two little-reported aspects of inadequate vaccination were found in the 2015/2016 survey: the mother's selfperception of happiness and the black skin color. A study conducted in the same Brazilian region did not observe this association, despite factors (eg, maternal and perinatal morbidity and mortality) describing the non-white race as a component of inadequate prenatal care and gestational syphilis. ${ }^{30}$ Strategies for these populations can be considered the starting point to reduce these inequities. ${ }^{31}$ The mother's self-perception of happiness may indicate proactive and self-care behaviors that can be extended to the family, especially the children, leading to vaccination prioritization and well-being, health, and life promotion.

Vaccination coverage was consistent with official data from Brazil and the state of Pernambuco and factors related to vaccine inadequacy were identified in Pernambuco. Sample size calculation was performed to analyze a set of variables for different purposes and may have affected the generalization of findings. The effect of factors related to the local health service (ie, vaccine availability and influence of health professionals' knowledge on vaccine administration) were not evaluated. It is worth mentioning that attitudes, perceptions, and mothers' opinions about vaccination were not addressed in this study; thus, this relevant aspect must be adequately considered in the current scenario and further studies.

We conclude that DTP3 demonstrated a growing trend over 25 years but remained below the target in all surveys. Reasons for this decline are complex, multifactorial, and depend on socioeconomic, political, and health care contexts, as well as subjective factors, such as the maternal perception of happiness. Results established a state of alert that must be appropriately valued and urgently considered due to their unfavorable perspectives. In addition, reinforcing policies to minimize inequality of access and eliminate existing social inequalities are still an important strategy to achieve levels of vaccination that ensure protection against preventable diseases for all children.

\section{Disclosure}

The authors report no conflicts of interest for this work.

\section{References}

1. United Nations International Children's Emergency Fund. Monitoring the situation of children and women; 2005. Available from: https:// data.unicef.org/topic/child-health/immunization/. Accessed August 17, 2020.

2. World Health Organization (WHO). Statement of the twenty-fifth polio IHR emergency committee; 2020. Available from: https://www.who. int/news/item/23-06-2020-statement-of-the-25th-polio-ihr-emergencycommittee. Accessed August 11, 2021.

3. World Health Organization (WHO); United Nations International Children's Emergency Fund. Progress and challenges with achieving universal immunization coverage; 2020. Available from: https:// www.who.int/immunization/monitoring_surveillance/who-immuniz. pdf. Accessed August 17, 2020.

4. Ghosh A, Laxminarayan R. Demand- and supply-side determinants of diphtheria-pertussis-tetanus nonvaccination and dropout in rural India. Vaccine. 2017;35(7):1087-1093. doi:10.1016/j.vaccine.2016.12.024

5. Phoummalaysith B, Yamamoto E, Xeuatvongsa A, et al. Factors associated with routine immunization coverage of children under one year old in Lao People's Democratic Republic. Vaccine. 2018;36(19):26662672. doi:10.1016/j.vaccine.2018.03.051

6. Hosseinpoor AR, Bergen N, Schlotheuber A, et al. State of inequality in diphtheria-tetanus-pertussis immunisation coverage in low-income and middle-income countries: a multicountry study of household health surveys. Lancet Glob Health. 2016;4(9):e617-26. doi:10.1016/ S2214-109X(16)30141-3

7. Pan American Health Organization; World Health Organization. Strategic plan of the Pan American Health Organization 2014-2019: championing health: sustainable development and equity. Pan American Health Organization. Regional office of the World Health Organization official document; 2014. Available from: https://www. paho.org/hq/dmdocuments/2017/paho-strategic-plan-eng-2014-2019. pdf. Accessed July 17, 2020. 
8. World Health Organization. World health statistics 2019: monitoring health for the SDGs, sustainable development goals. Geneva: World Health Organization; 2019. Available from: https://apps.who.int/iris/ handle/10665/324835. Accessed July 17, 2020.

9. Burton A, Monasch R, Lautenbach B, et al. WHO and UNICEF estimates of national infant immunization coverage: methods and processes. Bull World Health Org. 2009;87(7):535-541. doi:10.2471/BLT.08.053819

10. World Health Organization. Immunization coverage; 2020. Available from: https://www.who.int/en///news-room/fact-sheets/detail/immuni zation-coverage. Accessed August 20, 2020.

11. World Health Organization. Global vaccine action plan regional reports on progress towards GVAP goals. Annex to the GVAP secretariat annual report 2018. Geneva: World Health Organization; 2018. Available from: https://www.who.int/immunization/global_vaccine action_plan/web_regional_gvap_reports_2018.pdf. Accessed August 20, 2020.

12. Cruz RCS, Moura LBA, Soares Neto JJ. Conditional cash transfers and the creation of equal opportunities of health for children in low and middle-income countries: a literature review. Int J Equity Health. 2017;16(1):161. doi:10.1186/s12939-017-0647-2

13. Girmay A, Dadi AF. Full immunization coverage and associated factors among children aged 12-23 months in a hard-to-reach areas of Ethiopia. Int J Pediatr. 2019;2019:1924941. doi:10.1155/2019/ 1924941

14. Conselho Nacional dos Secretários de Saúde. A queda da imunização no Brasil [Reduction of immunization in Brazil]; 2017. Available from: https://www.conass.org.br/consensus/queda-da-imunizacao-bra sil/. Accessed August 20, 2020. Portuguese.

15. Lee CHJ, Overall NC, Sibley CG. Maternal and paternal confidence in vaccine safety: whose attitudes are predictive of children's vaccination? Vaccine. 2020;38(45):7057-7062. doi:10.1016/j.vaccine.20 20.09.020

16. Arroyo LH, Ramos ACV, Yamamura M, et al. Áreas com queda da cobertura vacinal para BCG, poliomielite e tríplice viral no Brasil (2006-2016): mapas da heterogeneidade regional [Areas with declining vaccination coverage for BCG, poliomyelitis, and MMR in Brazil (2006-2016): maps of regional heterogeneity]. Cad Saude Publica. 2020;36. Portuguese. doi: 10.1590/0102-311X00015619

17. Amaral NC. Com a PEC 241/55 (EC 95) haverá prioridade para cumprir as metas do PNE (2014-2024)? [With PEC 241/55 (EC 95), will priority comply with the PNE (2014-2014) Goals?]. Rev Bras Educ Med. 2017;22. Portuguese. doi:10.1590/S141324782017227145

18. Silva FS, Barbosa YC, Batalha MA, et al. Incompletude vacinal infantil de vacinas novas e antigas e fatores associados: coorte de nascimento BRISA, São Luís, Maranhão, Nordeste do Brasil [Incomplete childhood immunization with new and old vaccines and associated factors: BRISA birth cohort, São Luís, Maranhão State, Northeast Brazil]. Cad Saude Publica. 2018;34. Portuguese. doi:10.1590/0102-311X00041717

19. Giambi C, Fabiani M, D’Ancona F, et al. Parental vaccine hesitancy in Italy - results from a national survey. Vaccine. 2018;36 (6):779-787. doi:10.1016/j.vaccine.2017.12.074

Risk Management and Healthcare Policy

\section{Publish your work in this journal}

Risk Management and Healthcare Policy is an international, peerreviewed, open access journal focusing on all aspects of public health, policy, and preventative measures to promote good health and improve morbidity and mortality in the population. The journal welcomes submitted papers covering original research, basic science, clinical \& epidemiological studies, reviews and evaluations,
20. World Health Organization. Ten threats to global health - 2019 GPW13- the 13th general programme of work; 2019. Available from: https://www.who.int/emergencies/ten-threats-to-global-healthin-2019. Accessed August 20, 2020.

21. Hajizadeh M. Socioeconomic inequalities in child vaccination in low/ middle-income countries: what accounts for the differences? $J$ Epidemiol Community Health. 2018;72(8):719-725. doi:10.1136/ jech-2017-210296

22. Victora CG, Aquino EM, do Carmo Leal M, Monteiro CA, Barros FC, Szwarcwald CL. Maternal and child health in Brazil: progress and challenges. Lancet. 2011;377(9780):1863-1876. doi:10.1016/ S0140-6736(11)60138-4

23. Paim J, Travassos C, Almeida C, Bahia L, Macinko J. The Brazilian health system: history, advances, and challenges. Lancet. 2011;377 (9779):1778-1797. doi:10.1016/S0140-6736(11)60054-8

24. Rêgo RCF, Larrea-Killinger C, Barreto ML. Impacto de um programa de saneamento ambiental na saúde fundamentos teóricometodológicos e resultados de pesquisa interdisciplinar [Impact of an environmental sanitation program on health theoretical-methodological foundations and interdisciplinary research results]. Salvador: EDUFBA2018. 483. Portuguese.

25. Macinko J, Mendonça CS. Estratégia Saúde da Família, um forte modelo de Atenção Primária à Saúde que traz resultados [The Family Health Strategy, a strong model of Primary Health Care that delivers results]. Saude Debate. 2018;42:18-37. Portuguese. doi:10.1590/ 0103-11042018s102

26. Mendel-van Alstyne JA, Nowak GJ, Aikin AL. What is 'confidence' and what could affect it?: a qualitative study of mothers who are hesitant about vaccines. Vaccine. 2018;36(44):6464-6472. doi:10.1016/j.vaccine.2017.09.007

27. Andrade MV, Chein F, Souza LR, Puig-Junoy J. Income transfer policies and the impacts on the immunization of children: the Bolsa Família Program. Cad Saude Publica. 2012;28:1347-1358. doi:10.1590/S0102-311X2012000700013

28. De Araujo Veras AAC, da Fonseca Lima EJ, Caminha MFC, et al. Vaccine uptake and associated factors in an irregular urban settlement in northeastern Brazil: a cross-sectional study. BMC Public Health. 2020;20(1):1152. doi:10.1186/s12889-020-09247-7

29. Barata RB, Ribeiro MC, de Moraes JC, Flannery B; Vaccine Coverage Survey G. Socioeconomic inequalities and vaccination coverage: results of an immunisation coverage survey in 27 Brazilian capitals, 2007-2008. J Epidemiol Community Health. 2012;66(10):934-941. doi:10.1136/jech-2011-200341

30. Benzaken AS, Pereira GFM, Cunha ARC, Souza FMA, Saraceni V. Adequacy of prenatal care, diagnosis and treatment of syphilis in pregnancy: a study with open data from Brazilian state capitals. Cad Saude Publica. 2020;36:e0057219.

31. Macêdo VC, Lira PIC, Frias PG, Romaguera LMD, Caires SFF, Ximenes RAA. Risk factors for syphilis in women: case-control study. Rev Saude Publica. 2017;51:78.

guidelines, expert opinion and commentary, case reports and extended reports. The manuscript management system is completely online and includes a very quick and fair peer-review system, which is all easy to use. Visit http://www.dovepress.com/testimonials.php to read real quotes from published authors. 